\title{
Reflection on Mediation: Interpreting a Book of Andrei Scrima
}

\author{
IOAN AlexANDRU TOFAN ${ }^{*}$
}

The article examines Father Scrima's concepts and ideas from published works after 1990 and manuscripts between 1960 and 1980. In these texts, he probes the relationship between mediated and immediate knowledge from a spiritual point of view. The theology of Spirit that Father Scrima develops points towards a liturgical understanding of the world in which mediation finds its meaning and value.

Keywords: mediation, Scrima, trace, Spirit, interpretation

\section{Introduction}

The following text has two overarching themes. First, in an attempt to open a discussion on the value and significance of mediation in theological knowledge, I provide background from Saint Paul's considerations on allvı $\gamma \mu \alpha$ in I Corinthians. Second, I illustrate this point in some of the texts published by Andrei Scrima after 1990. While Father Scrima did not reflect on mediation's problems, his major concepts and images (trace, the aquatic principle of the Spirit etc.) point towards a relationship with God that can be seen as a path, as a long detour through the forms and colors of the world, not as an ecstatic rapture or bliss.

The following can be read as a hermeneutical attempt to mirror two important issues regarding the spiritual experience: one found in Saint Paul's text, and the other in Andrei Scrima's writings published after his return to Bucharest.

Reading Andrei Scrima in this context also needs a preliminary methodological remark. In his case, biography and bibliography are intimately intertwined. He scarcely wrote anything besides what he was specifically asked for to write. As a result, his readers are always recognizing the ideas presented in his style. Timpul Rugului Aprins. Maestrul spiritual în tradiția răsăriteană (1996) is a deep insight into the origin of his spiritual experience, which is the encounter of Ioan Kulîghin, the confessor and spiritual guide of Antim Monastery, before Romania's communist era. It is written for the new intellectuals in Romania after communism's fall in 1989 and interprets

\footnotetext{
* Ioan Alexandru Tofan, Prof. PhD, Romanian Academy, Institute for the History of Religions, Strada Macazului 10, Bl. N, sc. B, ap. 19, Iași, atofanro@yahoo.com.
} 
an essential aspect of spiritual life which he called: the process of spiritual guidance. The book's Foreword, written by Andrei Pleșu, offers a comprehensive and insightful perspective into both biographical and spiritual details on this moments and encounters. For Father Scrima, the spiritual guidance (as paradigmatic form of mediation through a personal encounter) is the core of his life and activity, in all of their aspects. This is why I felt necessary to discuss this matter of spiritual guidance in more detail, before making more general observations about the mediated character of spiritual life.

A last preliminary word about spiritual guidance: Father Scrima uses some examples and references (Paisius Velichkovsky and Vasile of Poiana Mărului, Nicodemus the Hagiorite and Makarios of Corinth, Bernard de Clairvaux and Guillaume de Saint-Thierry) to speak about a phenomenon related to the problem of spiritual mediation, that of the "depersonalisation" of the guide, in relation with his disciple. The main idea is that mediation is meaningful only when seen under the sign of the Spirit, which gives it an "aquatic" nature: in order not to become an obstacle, it has to be read dynamically, fluid and not as a historical determined agency in the process of transmission.

\section{On mediation}

Saint Paul provides one of the essential Christian insights concerning attempts to pierce the visible: "For now we see through a glass, darkly ( $\dot{\varepsilon} v$ aivi $\gamma \mu \alpha \tau$ ); but then face to face: now I know in part; but then shall I know even as also I am known." (1 Cor. 13.12, King James Version). The classic reading of the fragment ${ }^{1}$ points out the reprisal of an Old Testament topic concerning revelation and prophecy: Num. 12.8, where God categorically asserts Moses' exceptionality among people: "With him I speak face to face, clearly and not in riddles; he sees the form of the Lord." In this context, the "riddle/enigma" (ailvı $\gamma \mu \alpha)$ seems to be a sign of an imperfection, of a shortcoming in relation to true knowledge, "face to face," which follows. The Greek-German lexicon of the New Testament and of early Christin literature drafted up by Walter Bauer (revised by Frederick William Danker ${ }^{2}$ ) identifies several meanings to the term "riddle": 1) it can be something to be deciphered, or, 2) an indirect way, mediated (mirrored) by communication. Anthony Thiselton highlights ${ }^{3}$ the last meaning in his commentary for this

\footnotetext{
${ }^{1}$ I must thank Emanuel Conțac for his bibliographical indications and for the rich conversations on this topic.

${ }^{2}$ Frederick William Danker, A Greek-English Lexicon of the New Testament and Other Early Christian Literature, trans. William Arndt et al. (Chicago: University of Chicago Press, 2000).

${ }^{3}$ Anthony C. Thiselton, The First Epistle to the Corinthians: A Commentary on the Greek Text (Grand Rapids: Eerdmans, 2001), 1068-71.
} 
Pauline fragment: a depreciative meaning of "mirroring" as lack of clarity cannot be fully argued, as the author points out, because Corinth was famous in that period for the quality of the mirrors manufactured. Saint Paul most likely suggests the idea of indirect knowledge - through the world - of the testimonies and of experiences, in opposition to the subsequent direct and "uninterrupted" knowledge. Consequently, knowledge "in part" does not suggest incompletion as a sign of error - Thiselton refers here to the commentaries made by Karl Barth concerning this fragment - but it represents, again, a sign of mediating (in the mundane way of being characteristic to humans) the complete, perfect view.

Once the mediated nature of knowledge becomes recognised as such, the first issue that arises is the relation to "immediate knowledge." By putting excerpts together from Numbers and 1 Corinthians, the focus shifts towards a clear subordination of the ambiguity-stricken mediation to the vision beyond the senses. Saint Maximus the Confessor concludes as follows:

every righteous action in this life, when compared with the future righteousness, is like a mirror containing the image of archetypal realities - not the realities themselves as they subsist according to their own form. And in this life all knowledge of lofty things, when compared with the future knowledge, is an enigma, possessing the reflection of the truth - but not the self-subsisting truth itself that will be revealed in the future. ${ }^{4}$

The thirst for the original, the longing for a definitive union with God - decisive in the way the Holy Fathers assess the telluric situation of man - determine a double consequence in what concerns the status of mediation. On one hand, it means "incompleteness" and "uncertainty", and on the other hand, it may be understood only by analogy with the genuine, immediate relation beyond the ages. Thus, for the same Saint Maximus the Confessor, "the enigma, on the other hand, is knowledge that - through the highest contemplative grasp of the divine principles attainable by human nature has received the impression of realities beyond intellection." 5

An issue that I briefly outline here is that mediation, as source and as particular architectonics of the truth, is provided between the edges of the world. Can mediation be thought of in any other way than by subordinating it to immediate knowledge? There is a vast literature dedicated to the "inter-

\footnotetext{
${ }^{4}$ Saint Maximos the Confessor, On Diffculties in Sacred Scripture: The Responses to Thalassios, trans. Fr. Maximos Constas (Washington DC: The Catholic University of America Press, 2018), 254-55. Saint Maximus does not deny that full knowledge is possible, but in interpreting the fragment he describes the status of "earthly" mediation spoken of by Saint Paul.

${ }^{5}$ Ibidem, 255.
} 
mediary" and to its role in filtering the blinding light coming from above. Each time, the medium, the mediation are seen not as a settling of estrangement, but as a source of familiarity with heaven, as a condition of beauty possibility as a modelling - from colours and scents - of the transcendence. The answer to the aforementioned question may be given from the perspective of an ontology specific to intermediary focusing on the issue of visibility: "the medium derives from the essentiality of the terms used to describe it - in the self-image of reception (of the vision addressed/focusing on the self) and of the viewed object at the same time - through the manifestation specific to each of the two terms (referent and reference) in this precise type of relationship. It enters into effect the existence specific to vision (i.e., the look), as well as the existence specific to the object seen (i.e., its visibility or imaginality), thus activating the quidditas of both in their encounter, namely in the image we receive or, rather, which reveals itself inside of us when looking at that object."

Hence, the enigma - a theological name for mediation - may be understood not so much as a limit, but as condition of possibility for knowledge: knowledge understood as a delay near the forms of the world and vectorially oriented towards a truth that never reveals itself as such.

\section{The issue of spiritual guidance}

Two attitudes prevail among those who write about Andrei Scrima. On one hand, a significantly biographical attitude; on the other, one reproducing to a certain extent the ecclesiastical guidance that the Father Scrima himself inserted constantly in his words and writings. In the former, the fascination stirred by this exceptional character, the astonishing spirit of adventure that carried him for decades to all the corners of the world, and the events to which he took part - all of them make up the stakes of describing a spiritual physiognomy. In the latter case, Andrei Scrima is present not as a character per se, but as an example of spiritual master whose words or thoughts are partially synthesised and integrated in the readers' own queries, in their own questions and searches. In a somewhat prophetical manner, Father Scrima was eager to escape - even while he was still alive - both ways of understanding him: he warns against both the "solidification" of an idol in the life of a human and the spiritual "summary" that may be extracted from it.

Halfway between the two aforementioned options, we find a phenomenon adhering intimately to the way of being of the deepest spiritual

\footnotetext{
${ }^{6}$ Andrei Plesu, Anca Vasiliu, Bogdan Tătaru-Cazaban, Ștefan Afloroaei provide several bibliographical references.

${ }^{7}$ Anca Vasiliu, Despre diafan (Iași: Polirom, 2010), 26-27 (my translation).
} 
experience: the discrete presence of the reference point as a trace to be deciphered. Upon interpreting a letter from the spiritual father of the Antim Monastery, Ioan Kulîghin, Father Scrima discusses at a certain point the "depersonalisation" specific to a spiritual father, to an abbot: "the characteristic feature of a Spiritual father is the deletion of their particular traits. The more you advance on this path, the more you lose appropriation; as you enter the truth, you become free of yourself." ${ }^{\prime}$ Therefore, a spiritual father looks currently more like a position than a substance: he is a conveyer of tradition, a vehicle of the Spirit, and a point of reference for the disciple. As a historical reflex of this situation - Father Scrima argues - it is interesting that in several cases of such spiritual relationships (master-disciple, we may call it, without any further theoretical scruples), the disciple is better known than the master. This was very much the case for Paisius Velichkovsky and Vasile of Poiana Mărului, for Nicodemus the Hagiorite and Makarios of Corinth, and finally for Bernard de Clairvaux and Guillaume de Saint-Thierry.

The same passage discussing such "depersonalisation" of a spiritual father subtly suggests his limits, too. A master may not choose to give up discretely on his relationship with the disciple on a methodological - or even less on an ethical - basis. This relationship entails a different "logic" of the existence, with its own rigours and a special language: it is that of the Spirit taking over the world and revealing the shattering enigma of the Son risen to Heaven. A spiritual father is "depersonalised" as being an "agent" of the Spirit because he understands his calling in the horizon of a spiritual reality that had been "unappropriated" itself, faceless, and fluid (Father Scrima talks in his manuscripts about an "aquatic principle" specific to the theology of the Spirit). "The Spirit - just like a Spiritual father - has no identity; it may be communicated only in total un-appropriation. He has no face. The Son has a face and the Father a name. The Spirit is the last revelation, the last self-giving gesture of the Deity, thus reaching the deepest intimacy level of the human being." ${ }^{10}$ This also explains the paradoxical encounter between the humility of a spiritual father in relation to the world and his infinite audacity of calling God (parrhesia). According to Father Scrima, the intimacy with the Spirit and with the "aquatic" existence of a spiritual father - not belonging to any particular place on Earth - leads to the coordinates of a spiritual master's way of being: always on the move, a foreigner par excellence, totally opened to the others and requesting absolute trust from a dis-

\footnotetext{
${ }^{8}$ André Scrima, Timpul Rugului Aprins. Maestrul spiritual în tradiția răsăriteană (București: Humanitas, 2000), 38 (my translation).

${ }^{9}$ An image, rather than a technical expression.

${ }^{10}$ Ibidem, 39 (my translation).
} 
ciple. Such trust does not derive from an epistemic certainty, but from the same overwhelming familiarity with the "environment", namely the gentle breeze of the Spirit. Here, Father Scrima stops his commentary to make a remark: "through depersonalisation, we do not un-appropriate the traits or the limits defining you as a person, but the limitations." 11 In other words, there are those that exclude, separate and lock up the being within a burdensome finitude. Those that remain - the "limits" - open and make possible the relationship. They articulate a presence, such as the rhythm providing consistency and a relative identity to a musical theme.

In an attempt to give a name to such paradoxical presence of a spiritual master, Father Scrima uses the suggestion of a possible ontology of the trace: "the specific trait of an envoy is that he is passing: he passes and he leaves a trace that makes you pass to a different status. Only what moves, what passes leaves a trace." 12 The trace is a "writing" requesting "deciphering" and thus leading beyond it, towards the reality making it present and constantly giving discrete testimony. Therefore, situated at the border between presence and absence, the trace is an open limit, an itinerary not allowing the person covering it to get lost. In Father Scrima's words, the trace does not "impose", but it "proposes."

In such an ontological situation, the trace is a species of transparency. ${ }^{13}$ It makes transcendence visible without turning it into an object; it inserts it discretely into the texture of reality, without delimiting it precisely. The trace does not instill a presence. On the contrary, it dislocates it, in order to look in it and beyond it, towards its all-encompassing origin. In another example, the symbol may be alongside the trace to provide transparency: "The Symbol does not stick to things; it represents their very structure, their presence and their beauty, as they are perfected in God." ${ }^{14}$ As transparencies, a thing, the world, or the teaching of a spiritual master become alive miraculously, they escape the opacity specific to objects and they become each - according to the same Father Scrima - a "you."

\footnotetext{
${ }^{11}$ Ibidem, 41 (my translation).

12 Ibidem, 44 (my translation).

${ }^{13}$ I have already approached this topic on several occasions: for instance, Ioan Alexandru Tofan, Omul lăuntric. André Scrima și fizionomia experienței spirituale (București: Humanitas, 2019) and Tofan, "Ce este de văzut," in Teologie și filosofie între Orient și Occident. Actele simpozionului internațional organizat de Centrul "Sfinții Petru și Andrei” și Academia Catolică Val de Seine, eds. Iulian Dancă, Jean-François Petit and Lucian Dîncă (Târgu-Lăpuș: Galaxia Gutenberg, 2020), 45-57.

${ }^{14}$ In a series of synopses on Yoga (N8.1-22), manuscript within the André Scrim Archive, Fund André Scrima, at the New Europe College, Institute of Advanced Studies in Bucharest (AAS-NEC in the rest of the text).
} 
Finally, the same concept may be applied concerning the options briefly mentioned in the second part. Both options - the one describing a biography and the one summarizing a spiritual message - may be recomposed as transparencies of the ineffable characterizing a destiny. Both mirror each other. They limit and interpret each other continuously in order to escape self-sufficiency and to access, thus, their own regime (i.e., of being traces of a singular, unrepeatable encounter with the Heavens). In addition, one of the objections brought by Father Scrima to the persons trying to determine his identity as a theologist ("I am not a theologist, but a monk" 15 ) may also be read - I believe - precisely as a delimitation from any "substantial", definitive formula of the existence. The infinity of monastic vocation - in relation to any particular face that a person may acquire - can only be perceived in a mediated setting, as an intertwining of transparent traces into thoughts, acts, and words and not as a way of being strictly defined by specific criteria and marks.

\section{Traces and intermediary spaces}

For Father Scrima, the traces I discussed above are embodiments of mediation. They tame transcendence and, more than that, they transform it - on the level of mundane perception - into a dynamic meaning and a rising reference point. Heavens are no longer - in this perspective - a limit, but a constant and discrete presence of the Earth - a restlessness replacing the forms and an inexplicable splendour of the hues. An icon pertaining to Rublev's School - "Icon of the Women at the Grave" has been interpreted by Father Scrima from this viewpoint:

or, with a discrete, elegant hand, the angel points to the empty tomb where the trace appears: it takes the form of the same white fabric covering the messenger. It is the perfectly preserved shroud that never left the body by decomposing its structure, but it has simply crossed it, because it already pertains to the world of Resurrection. The shroud covering the body that had truly died is left there as a trace. ${ }^{16}$

Furthermore, the angel's wings ensure - according to the same interpretation by Father Scrima - "the passage of the world's axis from the inclination spe-

\footnotetext{
${ }^{15}$ Anca Vasiliu, "André Scrima, străinul," in André Scrima, O gândire fără țărmuri. Ecumenism și globalizare, trans. Luminiţa Munteanu, Anca Manolescu, Miruna and Bogdan TătaruCazaban and Dan Savinescu (București: Humanitas, 2005), 22.

${ }^{16}$ Scrima, Timpul Rugului Aprins. Maestrul spiritual în tradiția răsăriteană (București: Humanitas, 2000), 68 (author's translation).
} 
cific to manifested condition to the zenith rectitude of Resurrection" ${ }^{17}$ and confer upon the trace the dynamic meaning that I mentioned above.

Another example can be found in the commentary to the Gospel of John. The entire text is marked by overwhelming tension between the unseen mystery and its perceptible signs. This Gospel is about "holiness" Father Scrima underpins - more precisely, about the way it reveals itself to the ineffable world above. Holiness is a name "coming from above, from Heavens, and it expresses the inner side of God, His greatness, and the fact that $\mathrm{He}$ is above all that is worldly." 18 The unseen glory of the One Above is for Father Scrima a power in continuous motion, a dynamic bridge between the worlds, while John the Evangelist actually describes the way that this dynamism articulates in signs and acts, just to condensate eventually in the plenitude of Easter. The tension between the seen and the unseen represents the foundation of the world and it ensures both its meaning and consistency. It manifests itself, for instance, in the "transparentising" of things because they end up "showing" more than they are. Hence, Jesus' persistence of asking the discipled whether they really knew who He was, whether they recognised the Father in the Son, as well as the unspoken glory in the events of time. From the same perspective, we can also understand the Saviour's sadness in the Gospel of Matthew, when "[a]n evil and adulterous generation seeketh after a sign" (Mt. 12:39). Transcendence is in each gospel - mostly in the Gospel of John - not a distinct reality or an autonomous ontological "area," but a certain "regime" thereof: dynamic, rising. The identification of transcendence is thus a methodology of vision, a deciphering of the world's writing, and a crossing of "mediations" making up this writing. And the condition of such crossing serves as a reminder - with no direct connection, naturally - to the Hegelian scenario of conscience experience. It is the persistence in the negativity of the path and the suspicion cast on any form of directedness: "the spiritual life seeds and grows slowly, not rapidly and easily. What seeds fasts blooms fast and wilts fast, because it has no roots. To make roots, it must die, fall deep into the ground. It takes time, patience, discretion, and hidden life for the Spirit to perfect Its work." 19

A third example comes from Father Scrima's biography. I started, actually, with a reference to the way in which such a biography is possible because in his case his own biography and the spiritual message con-

\footnotetext{
${ }^{17}$ Ibidem, 70 (my translation).

${ }^{18}$ Scrima, Comentariu integral la Evanghelia după Ioan (București: Humanitas, 2008), 12 (my translation).

${ }^{19}$ Ibidem, 153 (author's translation).
} 
veyed to others are not to be read distinctively, but as two mediations of the same spiritual experience. It is the fundamental condition of spiritual life, as Father Scrima envisages it: itinerance. He would always be found in a different place; he covered during his lifetime vast geographical spaces and multiple cultural oddities. Furthermore, he would discretely leave any situation, friendship, or discussion where he felt he would acquire roots or a stable identity. In 1957, he wrote from India to Benedict Ghiuș: "you are on your path only when the outer voyage intertwines the inner itinerary in as many cross signs; primacy no longer pertains, in such a case, to the path or to the other, but to the One embracing them through the signs of His presence and creating them through this embrace: indeed, this is the path towards the Living God and - outside Him - the journey is an illusion and entertainment." 20 Therefore, spiritual experience can only be a form of itinerance because its transcendent pole - the divine - is a path itself: not a substance, as it was often understood in western philosophical tradition, but an infinite life flow embracing creation. Father Scrima's itinerance is also an example of mediation. It articulates - under the form of an adventure one of the foundations of his thoughts; "the shortest path towards ourselves passes through the other." ${ }^{21}$

\section{An interpretation attempt: Spirit and mediation}

Father Scrima's insistence on the detours known by truth or on the essential delays accompanying any genuine spiritual encounter may have - at first glance - a psychological explanation. He was obsessed with details and always ready for discussions; he was in love with the beauty of the world and with its small mysteries. At the same time, there underlies a deeper reason: a particular theological specificity, which may be circumscribed to the experience of the Spirit when "after Christ's Incarnation, we have reached another moment, the last moment of the Revelation, namely the gift of the Spirit."22

Father Scrima's understanding of this gift by the Spirit is relevant in order to decipher the role that he ascribes to mediation. First, there is a central experience of the Spirit, from which one has to start: the Divine Liturgy. In a lecture held at Kaslik in 1970, Father Scrima starts from the premise that any liturgy is a "method," a way to bring the Cosmos back to its transcendent origin:

\footnotetext{
${ }^{20}$ Scrima, "Scrisoare către Benedict Ghiuș," in Ortodoxia și încercarea comunismului (București: Humanitas, 2008), 394 (my translation).

${ }^{21}$ Scrima, Experiența spirituală și limbajele ei (București: Humanitas, 2008), 25 (my translation).

${ }^{22}$ Ibidem, 170 (my translation).
} 
the liturgy is, thus, contemplative, if we duly understand that contemplation does not entail an ecstatic exit from time, but an overcoming by assuming the time; contemplation means deciphering the presence, the traces left by God within time. From a certain standpoint, contemplation is an exit, but an exit from dead appearance, from the oldness that we must transpose (transubstantiate) permanently into new life. ${ }^{23}$

Thus, the experience of the Spirit - fully accomplished during the mass has a hermeneutical nature: it actually means, according to Father Scrima, to acknowledge the encounter between the visibility of the world and the visibility of God. Christ Himself is - from this perspective - a "sign," and the moment of the Cross actually means the "conveyance" of the Spirit, the world's openness towards His manifestation. Father Scrima insists in this respect: Christ's words (i.e., the Gospels) find their full meaning not in a simple reading, but during the liturgy, as they are rhythmed and distributed throughout the period represented by the liturgical year: "He Himself came before us as the anointed, the Christ, the Messiah: anointed, which means marked. In this capacity, Christ became whole, thus becoming The Whole. He becomes whole for us in the Spirit." 24

The experience of the Spirit may also clarify in this context the hidden meaning of mediation. Not as incompleteness, as I was mentioning earlier, but as oriented dynamism of the world. The last does not subsist in its separation from transcendence, but it allows to be "in-formed" by it, modelled and spiritually "brought to life." The central moment of the mass (i.e., the Eucharist) describes the "resurrection" of the world is possible by "incorporating" the substance of the world into the inner substance of the human being: "I am liturgical insofar as I eucharistify because, by receiving the Eucharist myself, thus the epiclesis of the Spirit, I incorporate and transform in my turn - within my own Christlike substance - the substance of the world, mostly the one offered to me by the living creatures." 25

In what concerns the experience of the Spirit, mediation acquires a liturgical meaning. It is a calling to the resurrection of the Cosmos and, sometimes, a praise to the life revealed from within it. The same Spirit makes it possible to interpret the traces, to fill the absence they circumscribe with the wholeness of the rising meaning that it announces.

\footnotetext{
${ }^{23}$ Scrima, Biserica liturgică (București: Humanitas, 2005), 34 (my translation).

${ }^{24}$ Ibidem, 37 (my translation).

${ }^{25}$ Ibidem, 41-42 (my translation).
} 


\section{Conclusions}

Father Scrima equivalates - in his manuscripts left in the archives hosted by the "New Europe" College in Bucharest - the Spirit to an "aquatic" principle in theology. It cannot be represented iconographically per se (the dove is more of an allegory), but only through the multiplicity of the saints who gently cover the walls of churches. This is, to use the terms coined by Constantin Noica, the paradigm of the "One-multiple" which takes thought out of abstraction. Similarly, the Spirit takes the world out of its ontological limitations and orients it dynamically, fluently, and towards the skies. In a draft to an introductory text for an Indian journal, Father Scrima notes: "spirituality (...) does not mean at all abstraction, subjectivity, a disguised way to deny or escape the world; on the contrary, it is an incarnated truth which has to be found in every concrete human value, conferring them their superior efficiency and perennial meaning." 26

Mediation is thus part of the whole manifestation of the Spirit, as its way to surround alterity constantly and to "surrender" to alterity. As an aquatic principle - the way Father Scrima understands it - the Spirit may be even seen as the medium by excellence, as matrix and source at the same time. The "enigma" mentioned by Saint Paul is thus far from representing an obstacle in the way of "direct" knowledge. As a name given to mediation, it even becomes the original ground of truth, sung in the beautiful words and forms of the world. These words and forms determine Father Scrima - in a text about prayer - to be awed constantly by "les petites merveilles de son Amour [de Dieu] qui sont les créatures." ${ }^{27}$

\footnotetext{
${ }^{26}$ In "Consideraţii legate de apariţia unei reviste editate în India” (TNN21), in AAS-NEC.

${ }^{27}$ In "Notes sur l'oraison" (TNN11), in AAS-NEC: "the tiny miracles of God's love which are the things created" (author's translation).
} 